\title{
Biological Pest Control in Maize Crop in Brazil: A Review
}

\author{
Felipe Tascheto Bolzan ${ }^{1}$, Diego Nicolau Follmann ${ }^{2}$, Camila Bisognin Meneghetti ${ }^{1}$, Leila Cássia Picon ${ }^{3}$ \\ \& Ana Lúcia de Paula Ribeiro ${ }^{4}$ \\ ${ }^{1}$ Graduate Program in Agronomy, Farroupilha Federal Institute, São Vicente do Sul, Brazil \\ ${ }^{2}$ Department of Crop Science, Federal University of Santa Maria, Santa Maria, Brazil \\ ${ }^{3}$ Master of Law, University Passo Fundo, Brazil \\ ${ }^{4}$ Department of Agronomy, Farroupilha Federal Institute, São Vicente do Sul, Brazil \\ Correspondence: Diego Nicolau Follmann, Department of Crop Science, Federal University of Santa Maria, Rua \\ Lamartine Babo, $\mathrm{n}^{\circ}$ 108, Bairro Camobi, CEP 97105-230, Santa Maria, RS, Brazil. Tel: 55-55-996-068-170. \\ E-mail: diegonicolaufollmann@gmail.com
}

Received: September 3, 2019

doi:10.5539/jas.v11n18p187
Accepted: October 10, 2019 Online Published: November 15, 2019

URL: https://doi.org/10.5539/jas.v11n18p187

\begin{abstract}
The areas of maize production harbor a high number of insect species, some of which are considered pests that cause damage to the crop. The methods of pest control have been a cause of concern for the society since the use of chemicals and the environmental problems arising from this practice indicate the need to search for alternatives to control. In this sense, it is necessary to seek an agricultural production system that contemplates environmental sustainability and promotes biodiversity in the Agrosystem, among which the use of biological agents is highlighted. The objective of this research was to update through a bibliographic review the advances in the literature on biological control of maize crop pests. For the development of this article, we used the method of approach the analytical and as procedural method the monographic, through bibliographic research, using specialized doctrines, appropriate to the object of the study and legislations. Because of the observed aspects, it is possible to conclude that the group of natural enemies that act as biological control agents is formed by parasitoids, predators and entomopathogenic microorganisms. The rationalization of the use of chemicals should be associated with the use of biodefensives in integrated pest management. Advances in the legislation of biological products in Brazil are fundamental to give speed to the registration of new alternatives of biological control, aimed at the safety of the environment, human health and that are generated without the exploratory use of biodiversity.
\end{abstract}

Keywords: pest management, natural enemies, sustainable agriculture, Zea mays L.

\section{Introduction}

Pest control methods have been the cause of concern for society. The increase in the costs of chemical control, the loss of efficiency of some of these products and the environmental problems arising from these practices, indicate the necessity to research alternatives of control. It is necessary to seek an agricultural production system that contemplates environmental sustainability and promotes biodiversity in the Agrosystem, among which the use of biological agents (Simonato, 2018).

Biological control is a natural phenomenon that consists of regulating the number of species by natural enemies, which constitute the agents of biotic mortality. Thus, all living beings have natural enemies attacking their various stages of life. Among these, there are quite diversified groups, such as insects, viruses, fungi, bacteria, nematodes, mites and spiders (Abreu et al., 2015).

Nowadays, the biological control is indispensable in the Integrated Pest Management Program (IPM), because it combines cultural and chemical practices for resistance management, with real gains in grain yield. This tool is the way that rationalizes the control of pest insects of crops with natural processes and the rational use of agricultural pesticides for pest control (Simonato et al., 2014).

The benefits of IPM results in greater stability in pest populations also for subsequent crops capable of satisfying food production needs, without unduly causing damage to the basis of an ecosystem (Simonato, 2018). This technology guides the decision-making of pest control based on a set of information about insects and their 
population-density, the occurrence of natural enemies and the ability of the culture to tolerate the damage (Oliveira \& Avila, 2010). Thus, the monitoring of the crop, the correct identification of pests and natural enemies and the knowledge of the development stage of the plant are important to achieve good results. The new mentality of the productive sector (IPM) grows at an accelerated pace and biological pesticides are paramount in this system.

According to the Brazilian Association of Biological Control Companies (ABC Bio, 2019), through their modes of action, the biodefensives are highly specific to the target pest, which allows the life of beneficial insects. Most biodefensives are exempt from maximum residue limits in food worldwide, reducing the exposure of consumers and the environment to toxic waste. In this way, it is possible to achieve high-efficiency indices in the management, and gradual reduction of the need for inputs, which enables the producer to increase the income of his/her crop.

The advancement of scientific knowledge in the area of biological pest management in annual crops is constant and dynamic, in this sense compiling data from research results on the subject assist technicians and rural producers to update on the novelties of integrated pest Management using biological control. In this sense, the objective of this article was to conduct research in relevant publications in recent years and update information through a bibliographic review of the advances in the literature on biological control of maize crop pests in Brazil.

\section{Historic of Biological Control}

The first case of success of classical biological control was the importation of the ladybird Rodolia cardinalis by the USA of Australia in 1888, for control of the cochineal of the citrus Icerya purchasi in California (Bueno, 2015). In Brazil, there are several cases of successful use of biological control in several cultures. The first classical biological control project was the introduction of the Prospaltella berlesi microhimenopter for the control of the white cochineal of the mulberry Pseudoaulacaspis pentagone, in 1921 (Embrapa, 2003).

In April 1974 began the national program of biological control of sugarcane borer (Diatraea Saccharalis) with the introduction in the state of Alagoas of Cotesia flavipes from Trinidad Tobago (Bueno, 2015). The control of Diatraea Saccharalis, the main pest of sugarcane crop in Brazil, is performed with biological control agents, the larval parasitoid Cotesia flavipes and the egg parasitoid Trichogramma sp. (Simonato et al., 2014).

The species Trichogramma sp. is a parasitoid of the most studied and used in the world, since the beginning of the last century. In 1984, in the Department of Entomology and Acarology of ESALQ/USP, the program of biological control of agricultural pests with Trichogramma began. It was a program containing different stages, multidisciplinary and that today begins to be widely used in Brazil, with inundative liberations (Parra, 2019).

The Baculovirus, as a biological alternative to the chemical control of the soybean Caterpillar (Anticarsia gemmatalis) in Brazil, dates back to the decade of 70. In the year 1972, in the region of Campinas in the state of São Paulo and later in other regions was detected Baculovirus anticarsia (Secchi, 2002). In the years 80, the Baculovirus anticarsia, present in about $10 \%$ of the soybean caterpillars, was multiplied, reaching $10 \%$ of the area cultivated with soybean in Brazil (Oliveira et al., 2018).

In 1986, the Parasitoid Telemonus remus, originating in Malaysia and New Guinea, was introduced in Brazil. It is considered a successful methodology in several countries such as Colombia and Venezuela, which reaches control levels of up to 90\% (Cunha, 2017). In the years 90, the use of the parasitoid Trissolcus basalis for the control of Phytophagous bedbugs began to be widespread. With the use of egg parasitoids of bedbugs, mortality rates between $65 \%$ and $90 \%$ were found, according to the host species (Oliveira et al., 2018).

At the end of the decade of 90 , the use of Baculovirus anticarsia became the largest biological control program at the time. Currently, other types of baculovirus of agricultural pests have been developed (Simonato et al., 2014). With the development of new technologies, in the year 2007, there was the first release of a transgenic maize plant in Brazil that expresses the Cry1 Ab protein of Bacillus thuringiensis (Bedin et al., 2015). In 2010, the first Bt event in insect-tolerant soybean was approved. We can cite the use of Bacillus thuringiensis for the control of defoliating caterpillars in different cultures.

One of the largest biological control programs in the world is Brazilian, with the control of sugarcane pests. The sugarcane areas of the country make use of this technology, with very high control efficiency and good results at the field level (Simonato et al., 2014). Biological control has been assuming great importance in Brazil both for the results already demonstrated by the research and the need to reduce pesticides in the environment. To implement biological control, the joint action of research, rural extension and producers is one of the best strategies (Embrapa, 2015). 
According to the Brazilian Association of Biological Control Companies (ABC Bio, 2019), the global market for organic pesticides has recorded growth rates five times higher than the chemical pesticide industry. The trend is the same in Brazil, with expressive consumption in the coming years motivated by the limited supply of new chemical molecules. The limited use of chemical molecules by producers allows the resistance of pests, as well as the practice of continuous cultivation, contributes to the proliferation of new pests in cultivation environments. These factors drive to generate alternatives using biological control; technological advances offer the development of more efficient biological products (Valicente, 2015).

The increasing incompatibility, research, and development studies enable the use of biological pesticides compatible with synthetic pesticides. This combination contributes to extending the shelf life of synthetic products using rotation with biological or combination with biological (Mattei et al., 2017). The evolution continues on the scale of production and methods of application and storage, making this biological input increasingly efficient and accessible to the user. It is important to emphasize that biological control cannot be seen only as an isolated activity within an IPM, should be analyzed from a global point of view to broaden its utilization spectrum.

\section{Biological Control Agents}

The maize crop houses a large number of insect species, some of which are considered pests that cause damage to crops. However, there is a range of species of natural enemies that can assist in pest control (Cruz, 2015). The group of Natural enemies that act as biological control agents is formed by parasitoids, predators and entomopathogenic microorganisms.

Parasitoids are insects that develop in a single individual, most of them belong to the order Hymenoptera, being specific to a particular species, or a group of species (Bueno, 2015). They are small was as that oviposit and develop in various stages of insects, have a great advantage concerning the use of chemical insecticides, which is the ability to parasitize eggs located in different regions of the plants, including in places where the sprayed insecticide spray on the crop hardly reaches (Simonato et al., 2014). Examples of parasitoids in the maize crop are Trichogramma sp., Telenomus sp., Cotesia flavipes, Celatoria Bosqi, Centistes gasseni, and Trissolcus basalis.

The predatory insects are present in various insect orders, being free-living individuals, can present the predator behavior, both in the nymphal and adult stages. As for the food, the habit may be chewing or sucking, they require a large number of prey to complete their life cycle (Bueno, 2015). Example of predator agent in maize crop is the Podisus niger, Doru luteipes, and Euborelia annulipes.

In addition to several insect species as biological control agents, there are other groups with great potentials, such as entomopathogenic microorganisms. The entomopathogenic microorganisms, such as fungi, bacteria, and viruses, cause the death of insect pests, contributing to the maintenance of pest populations below the control level (Picanço, 2010).

The microorganisms used in biological control as Entomopathogenic nematodes, bacteria, fungi, and viruses are advantageous due to specificity and selectivity, high multiplication capacity and dispersion in the environment, can be employed in association with selective insecticides, can be produced in artificial media in large quantities, besides the reduction of environmental contamination and toxicity to humans and other non-target organisms (Kaiser, 2016). Examples of entomopathogenic microorganisms can aid in the pest control in maize fungi Aspergillus flavus and Beauveria bassiana, Bacillus thuringiensis bacterium and as a virus Baculovirus.

\section{Biological Pest Control in Maize Crop}

The maize crop is a host of phytophagous insects of different species, which invariably cause economic losses to the country's production. In recent years, there has been an increase in the incidence of maize-specific pests and others related to the planting that precedes the crop (Cruz, 2015). The incidence of pests increases with continuous cultivation in tropical conditions, mainly by sowing second harvest maize, which is sown from January to March (Valicente, 2015).

The use of biological control has been a good option for the reduction of the use of agrotoxic in maize crops. To perform the correct control of the plague and need to know which of its natural enemies. Table 1 describes the relationship between parasitoids and pests in maize crop, obtained in the most frequent publications.

One of the most commonly used biological controls for the control of Lepidoptera in maize is Trichogramma sp. The female individual of this parasitoid lays her eggs inside the egg of the plague and the end of the biological cycle emerges the adult (Cruz, 2015). The great differential in favor of the exclusive biological control agents of eggs, consists in the reduction of the population of the pest, preventing injury to the plant, being efficient in the 
pest control Spodoptera frugiperda, Helicoverpa zea, Helicoverpa armigera (Pasini et al., 2017), Diatraea saccharalis (Santos \& Cruz, 2017), Elasmopalpus lignosellus (Xavier et al., 2011). In the parasitism of the eggs of Agrotis ipsilon, Trichogramma Pretisoum and Trichogramma Atopovirilia stand out demonstrating high potential for use in pest management (Kaiser, 2016).

Microbial control is considered a safe method for humans and the environment, highlighting the bacterium Bacillus thuringiensis. A typical characteristic of Bacillus thuringiensis is the production of protein crystals that usually occurs during sporulation, being toxic to some insect groups, because it has high specificity (Santos et al. 2018). The main strategy used to combat Spodoptera frugiperda is the use of corn hybrids, which express a type of insecticide protein called Bt (Cunha, 2017).

This bacterium is effectively toxic to the insects of the order Coleoptera and Lepidoptera, being an alternative of control aiming the management of pest insects in the maize crop (Galzer \& Azevedo Filho, 2016). Biological control with Bacillus thuringiensis has shown good results in the control of Spodoptera frugiperda (Machado et al., 2018), Helicoverpa zea (Araújo \& Valicente, 2018), Helicoverpa armigera (Santos et al., 2016), Agrotis Ipsilon (Menezes et al., 2011). Recent researches have shown interest in developing biological pesticides and transgenic plants resistant to Elasmopalpus lignosellus larvae due to the insecticide potential found in Bacillus thuringiensis proteins (Zorzetti et al., 2017).

Baculoviruses comprise the most common and most studied group among insect pathogenic viruses. This is because viruses have the greatest potential to be used as biological pest control agents (Valicente, 2015). The Infection of the insect by the virus occurs after the ingestion of the occluded forms that are dissolved in the intestine (Diniz, 2018). In the maize crop, Baculovirus shows efficient control of the larvae, Spodoptera frugiperda (Cunha, 2017), Helicoverpa armigera (Kuss, 2016). In addition, the use of pathogenic viruses baculovirus Agrotis ipsilon multiple Nucleopolyhedrovirus (AgipMNPV) that are of a specific action, high virulence and with the ability to replicate in the host for control of Agrotis Ipsilon (Kaiser, 2016).

Among the predatory insects, the Podisus Nerispinus bug is important in the integrated pest management, acting as a biological control agent of different species of defoliating caterpillars. The occurrence of Podisus nirispinus in several crops shows the possibility of its use in flood releases for pest-insect suppression and its use in integrated pest management programs (Botteon et al., 2016). The species Podisus nirispinus in field conditions, the adult females and nymphs of the fifth urge predated 2.26 and 1.73 larvae/day of Helicoverpa armigera, respectively (Simonato, 2018).

The parasitoid Telemonus sp., exclusive of eggs, is also used as a tactic of biological control of pest in the maize crop, capable of parasailing all layers of the host's eggs. The females that parasite the eggs and can work both during the day and the night, which increases the chances of parasiting also newly-hatched eggs (Cunha, 2017). With the correct use of this parasitoid, the field is possible through the release of Telemonus sp. In three consecutive weeks the control of eggs Spodoptera frugiperda in maize (Ivan et al., 2016) and acts as a population regulator of several species of Bedbugs, including Dichelops melacanthus (Pinto et al., 2017). The Telemonus sp. is an excellent egg parasitoid of the Euschistus heros, emphasizes the importance of IPM and the use of management tactics with selective insecticides to control the level of activity of the Bedbug (Favetti, 2018).

Cotesia flavipes is a parasitoid wasp, the female Ovoposita and develops inside the larvae or pupae of other insects. This parasitoid has specificity for caterpillars of Diatraea saccharalis (Silva, 2018). The use of Cotesia flavipes is the biological control form of Diatraea saccharalis most widespread and used in Brazil, but the parasitism of the agent is more common in more developed urge caterpillars when they are in the third to the sixth instars (Holzhausen, 2017).

The insects Doru luteipes and Euborelia annulipes are popularly known as treasons and are efficient predators of pests of importance in maize crops, such as Spodoptera frugiperda, Helicoverpa zea, Helicoverpa armigera and Aphthous (Ribeiro, 2017). Biological control can be a promising tactic for the management of the Diabrótica speciosa Pest since several natural enemies described in the literature are known to affect the development of adults and larvae. The parasitoids that have been used are the Celatoria Bosqi and the Centistes Gasseni (Dedonatti, 2017).

Among the alternatives of egg parasitoids, Trissolcus Basalis emerges with the potential for biological control programs of bedbugs (Rocha, 2016). The Trissolcus basalis shows preference in parasitizing eggs of Nezara viridula, however, it can be an alternative control of Euschistus heros and Dichelops melacanthus in maize (Madaloz \& Policena, 2018). 
The impact of natural enemies on the species Elasmopalpus lignosellus larvae is considered low due to the protected habitat. However, the entomopathogenic fungi Aspergillus flavus and Beauveria Bassiana are related as natural enemies (Sousa, 2016). Beauveria bassiana is a fungus naturally found in the soil that acts as parasites, causing diseases in insect pests. The control with the fungus Beauveria Bassiana showed satisfactory results for the control of the first and third instar Elasmopalpus lignosellus (Magnabosco, 2018). The use of Beauveria Bassiana is an effective control strategy of the Euschistus heros and to minimize the damage caused by insects (Zambiazzi et al., 2012).

The fungus Beauveria bassiana was efficient in to cause vitro mortality of Helicoverpa zea (Zambiazzi et al., 2016). The species Beauveria Bassiana and Metarhizium anisopliae are promising alternatives of entomopathogenic fungi as possible tools in the management of biological control of Diatraea saccharalis (Rodrigues et al., 2016) and Agrotis Ipisilon due to toxins that these fungi release in the Insects (Gabarty et al., 2014).

Other agents of biological pest control can be cited, as examples the ladybugs, Chrysopidae larvae, flies of the Syrphiidae family and parasitoid wasps of the wheat Caterpillar (Pseudaletia sequax), corn aphid (Rhopalosiphum maidis), Corn leafhopper (Dalbulus maidis), Stink bug (Dichelops furcatus). Moreover, the parasitoid wasp of Eggs (Scelionidae) and flies (Tachinidae) for the control of the Corn Bug (Leptoglossus zonatus).

Table 1. Relation of parasitoids and pests in maize crop, control alternatives

\begin{tabular}{|c|c|c|}
\hline Antagoninsts & Pest & Author \\
\hline \multirow{6}{*}{ Trichogramma sp. } & Armyworm (Spodoptera frugiperda) & Pasini et al., 2017 \\
\hline & Corn earworm (Helicoverpa Zea) & Pasini et al., 2017 \\
\hline & Cotton bollworm (Helicoverpa armigera) & Pasini et al., 2017 \\
\hline & Sugarcane borer (Diatraea saccharalis) & Santos \& Cruz,2017 \\
\hline & Black cutworm (Agrotis Ipsilon) & Kaiser, 2016 \\
\hline & Lesser cornstalk borer (Elasmopalpus lignosellus) & Xavier et al., 2011 \\
\hline \multirow{4}{*}{ Bacillus thuringiensis } & Armyworm (Spodoptera frugiperda) & Machado et al., 2018; Cunha, 2017 \\
\hline & Corn earworm (Helicoverpa zea) & Araújo \& Valicente, 2018 \\
\hline & Cotton bollworm (Helicoverpa armigera) & Santos et al., 2016 \\
\hline & Black cutworm (Agrotis ipsilon) & Menezes et al., 2011 \\
\hline \multirow{3}{*}{ Baculovirus } & Armyworm (Spodoptera frugiperda) & Cunha, 2017 \\
\hline & Cotton bollworm (Helicoverpa armigera) & Kuss, 2016 \\
\hline & Black cutworm (Agrotis Ipsilon) & Kaiser, 2016 \\
\hline Podisus nigrispinus & Cotton bollworm (Helicoverpa armigera) & Simonato, 2018 \\
\hline \multirow{3}{*}{ Telenomus sp. } & Armyworm (Spodoptera frugiperda) & Ivan et al., 2016 \\
\hline & Neotropical brown stink bug (Euschistus heros) & Favetti, 2018 \\
\hline & Stink bug (Dichelops melacanthus) & Pinto et al., 2017 \\
\hline Cotesia flavipes & Sugarcane borer (Diatraea saccharalis) & Holzhausen, 2017 \\
\hline Aspergillus flavus & Lesser cornstalk borer (Elasmopalpus lignosellus) & Sousa, 2016 \\
\hline \multirow{4}{*}{ Beauveria bassiana } & Lesser cornstalk borer (Elasmopalpus lignosellus) & Magnabosco, 2018 \\
\hline & Neotropical brown stink bug (Euschistus heros) & Zambiazzi et al., 2012 \\
\hline & Corn earworm (Helicoverpa zea) & Zambiazzi et al., 2016 \\
\hline & Sugarcane borer (Diatraea saccharalis) & Rodrigues et al., 2016 \\
\hline \multirow{2}{*}{ Trissolcus basalis } & Neotropical brown stink bug (Euschistus heros) & Madaloz \& Policena, 2018 \\
\hline & Stink bug (Dichelops melacanthus) & Madaloz \& Policena, 2018 \\
\hline & Armyworm (Spodoptera frugiperda) & Ribeiro, 2017 \\
\hline Doru luteipes & Corn earworm (Helicoverpa zea) & Ribeiro, 2017 \\
\hline \multirow[t]{2}{*}{ Euborelia annulipes } & Cotton bollworm (Helicoverpa armigera) & Ribeiro, 2017 \\
\hline & Aphids & Ribeiro, 2017 \\
\hline $\begin{array}{l}\text { Celatoria bosqi } \\
\text { Centistes gasseni }\end{array}$ & Cucurbit beetle (Diabrotica speciosa) & Dedonatti, 2017 \\
\hline \multirow{2}{*}{ Metarhizium anisopliae } & Black cutworm (Agrotis ipsilon) & Gabarty et al., 2014 \\
\hline & Sugarcane borer (Diatraea saccharali) & Rodrigues et al., 2016 \\
\hline
\end{tabular}




\section{Interaction Between Chemical and Biological Control}

Pest control has been based on chemical control, one of the ways to minimize the use of pesticides is through the increment of biological control, which presents itself as an important and viable alternative. However, we must provide conditions for these natural enemies, both those of natural occurrence in the area, like those that can be used through flood liberations, can be effective and play their role (Simonato et al., 2014). For this purpose, the selectivity and compatibility of phytosanitary products in IPM programs are important when choosing the insecticide or the way to apply it, aiming at preserving the natural enemies and at the same time, controlling the insect pests (Oliveira et al., 2018). Those who are recognized as selective to natural enemies should be prioritized.

However, the limited investment in research, the difficulty of laboratories close to producers, the breakdown of the paradigm and the implementation of biological control in the scope of integrated pest management, are restrictive factors the expansion of biological control. It is necessary to elaborate on public policies to encourage the use of biological control agents, as well as the development and regulation of research and registration of products based on biological control agents.

\section{The Regulation for the Use of Pest Biocontrol in Brazil}

The use of products based on biological agents for pest control and plant diseases (biocontrol) has experienced strong growth in recent years in Brazil. This fact has contributed to significant advances in Brazilian legislation concerning these products. There are currently a series of governmental guidelines that guide all the necessary steps to regulate the production and use of organic products, which guarantees the productive sector clear rules and the final consumer the certainty of the availability of Safe products to the environment, to human health and generated without the exploratory use of biodiversity.

Currently, biological pest control in Brazil is based on the Pesticide Law-Law 7,802 of July 11, 1989, which defines an agrochemical category product such as:

[...] Products and agents of physical, chemical or biological processes intended for use in the production sectors, storage and processing of agricultural products, pastures, protection of forests, native or implanted, and other ecosystems and Also of urban, water and industrial environments, whose purpose is to alter the composition of the flora or fauna, in order to preserve them from the harmful action of living beings considered noxious.

At this point, biological control agents (parasitoids, predators, and nematodes), microbiological control agents (fungi, bacteria, and viruses), semiochemicals, other biochemical, plant and mineral extracts, used in Agriculture to control organisms deemed harmful. In Brazil, the Ministry of Agriculture Livestock and Supply (MAPA), the National Health Surveillance Agency (Anvisa) and the Brazilian Institute of Environment and Renewable Natural Resources (Ibama) are the federal agencies responsible for the evaluation and Registration of pesticides and the like. All registration requests must be submitted to each of these organs.

Considered pesticides by legislation, biocontrollers are treated as chemical molecules, when they are not registered according to the rules of products for organic farming. Thus, the same rules applied to chemicals are valid for biologicals, in matters of special transport, segregated storage and disposal of packaging, the fact that the biocontrollers are under the umbrella of the law governing the Defensives Chemicals makes it difficult to stimulate investment in research and development, there is no advance, due to the imposition of difficulties in registering an innovation.

In this sense, to bring about the process of evaluation and registration of Pest Biocontrollers in 2002, the Decree $\mathrm{n}^{\mathrm{o}} 4,074$ was instituted, and it is defined that the products of low toxicity and dangerousness should have the evaluation of their demands of Prioritized records.

From 2005 onwards, four normative regulations were published regulating some categories of products of biological origin. Thus, to regulate the registration of products of biological origin, we count today with four joint normative instructions (INCs), which differentiate them between biochemists; Semiochemicals Biological control agents; and microbiological control agents. These four standards have established differentiated protocols for each of these categories and have inaugurated two major advances in simplifying the registration of these products. The first is to have a toxicological evaluation and a phased environmental hazard, in which only certain types of laboratory studies are requested in case of evidence of harmful actions in the first phase of the evaluation. The second is the dispensation of various types of laboratory studies, required for the registration of conventional chemical pesticides, according to the nature of the substance or the intended form of use. 
The products framed as biological control agents are regulated by the joint normative instruction-INC No. 2/2006 (MAPA, ANVISA, \& IBAMA, 2006b). The last category of products of biological origin that is already regulated is that of microbiological control agents, standardized by INC No. 3/2006 (MAPA, ANVISA, \& IBAMA, 2006c). The standard defines them as:

Live microorganisms of natural occurrence, as well as those resulting from techniques involving the natural introduction of hereditary material, except for organisms whose genetic material (DNA/RNA) has been modified by any technique of Genetic Engineering (GMOS) (MAPA, ANVISA, \& IBAMA, 2006c).

Some years after the publication of the product standards of biological origin, there was another significant regulatory advance. Three normative acts were published that enabled the registration of products of the semiochemical categories, biological control agents (natural enemies) and microorganisms, by biological target (MAPA, 2010, 2011, 2014).

Although complex and often costly, Brazil has a legal structure for the regulation of the production and use of biological products, which guarantees the productive sector clear and egalitarian rules to all and the final consumer the certainty of the availability of safe products to the environment, to human health and generated without the exploratory use of biodiversity.

\section{Conclusion}

Given the observed aspects, it was possible to note that the use of biological control has been a good option to reduce the incidence of pests in maize crop in Brazil, it is an increasingly important tool in the Integrated Pest Management program.

Advances are still needed in the legislation of biological products in Brazil so that there is a greater speed in the evaluation and registration processes based on the preservation of the environment, human health, and preservation of biodiversity.

\section{References}

Abreu, J. A. S., Rovida, A. F. D. S., \& Conte, H. (2015). Controle biológico por insetos parasitoides em culturas agrícolas no Brasil: Revisão de literatura. Revista Uningá, 22(2), 22-25. Retrieved from http://revista.uninga.br/index.php/uningareviews/article/view/1626

Araújo, J. B. T., \& Valicente, F. H. (2017). Meios de cultura alternativos para a produção de biopesticida à base de Bacillus thuringiensis, para o controle da Spodoptera frugiperda e Helicoverpa armigera. Embrapa Milho e Sorgo, Brazil. Retrieved from https://www.alice.cnptia.embrapa.br/bitstream/doc/1086615/1/ Meioscultura.pdf

Associação Brasileira das Empresas de Controle Biológico. (2019). Controle biológico no Brasil. Retrieved from http://www.abcbio.org.br/controle-biologico-no-brasil

Bedin, F. A., Assmann, E. J., Polo, L. R. T., \& Schuster, I. (2015). Eficiência de eventos transgênicos de resistência a insetos em soja e milho. Retrieved from https://www.fag.edu.br/upload/revista/cultivando_o_ saber/55d1ef7ceb18d.pdf

Botteon, V. W., Neves, J. A., \& Godoy, W. A. C. (2016). Functional Response and Matrix Population Model of Podisus nigrispinus (Dallas, 1851) (Hemiptera: Pentatomidae) fed on Chrysomya putoria (Wiedemann, 1818) (Diptera: Calliphoridae) as Alternative Prey. Neotropical Entomology, 46(2), 137-143. https://doi.org/ 10.1007/s13744-016-0440-8

Brasil. (1989). Lei no 7.802, de 11 de julho de 1989. Dispõe sobre a pesquisa, a experimentação, a produção, a embalagem e rotulagem, o transporte, o armazenamento, a comercialização, a propaganda comercial, a utilização, a importação, a exportação, o destino final dos resíduos e embalagens, o registro, a classificação, o controle, a inspeção e a fiscalização de agrotóxicos, seus componentes e afins, e dá outras providências. Brasília: Congresso Nacional.

Brasil. (2002). Decreto no 4.074, de 4 de janeiro de 2002. Regulamenta a Lei no 7.802, de 11 de julho de 1989, que dispõe sobre a pesquisa, a experimentação, a produção, a embalagem e rotulagem, o transporte, o armazenamento, a comercialização, a propaganda comercial, a utilização, a importação, a exportação, o destino final dos resíduos e embalagens, o registro, a classificação, o controle, a inspeção e a fiscalização de agrotóxicos, seus componentes e afins, e dá outras providências. Brasília: Congresso Nacional. 
Bueno, V. H. P., Lins, J. C., Junior, A. M., \& Silveira, L, C. P. (2015). Controle biológico e manejo de pragas na agricultura sustentável. Universidade Federal de Lavas, Brazil. Retrieved from http://www.den.ufla.br/ attachments/article/75/ApostilaCB $\% 20 \% 28$ final $\% 29$.pdf

Cruz, I. (2015). Avanços e desafios no controle biológico com predadores e parasitoides na cultura do milho. Milho safrinha, XIII Seminário Nacional, Maringuá. Retrieved from https://www.alice.cnptia.embrapa.br/ alice/bitstream/doc/1030705/1/Avancosdesafios.pdf

Cunha, I. C. (2017). Controle biológico de spodoptera frugiperda: eficiência do uso de baculovirus spodoptera e outras técnicas (Dissrtação (Programa de Mestrado Profissional em Inovação Tecnológica), Universidade Federal do Triângulo Mineiro, Uberaba). Retrieved from file://C:/Users/Felipe/Downloads/2431-165032-PB.pdf

Dedonatti, E. (2017). Efeito do tratamento de sementes no manejo da larva alfinete, diabrotica speciosa (Germar, 1824) (Coleoptera: Chrysomelidae), e na produtividade da cultura do milho. Universidade Federal da Fronteira Sul, Chapecó. Retrieved from https://rd.uffs.edu.br/handle/prefix/1480

Diniz, N. F., Luski, P. G. G., Queiroz, A. P., Silva, N. R. A., Bueno, A. de F., Neves, P. M. O. J., \& Oliveira, M. C. N. (2018). Baculovirus spodoptera associado com herbicidas no controle de Spodoptera frugiperda. XIII Jornada Acadêmica da Embrapa Soja.

EMBRAPA (Empresa Brasileira de Pesquisa Agropecuária). (2003). Controle Biológico de Pragas: Princípios e Estratégias de Aplicação em Ecossistemas Agrícolas. Seropedia, Brazil. Retrieved from https://ainfo.cnptia. embrapa.br/digital/bitstream/item/86811/1/doc164.pdf

EMBRAPA (Empresa Brasileira de Pesquisa Agropecuária). (2015). EMBRAPA Milho e Sorgo. EMBRAPA, Brazil.

Favetti, B. M., Bueno, A. F., Silva, G. V., \& Diniz, N. F. (2018). Utilização de Telenomus podisi no manejo de Euschistus heros em soja. XXVII Congressa Brosileiro de Entomologia e X Congresso Latino-Americano de Entamologia. Retrieved from http://www.alice.cnptia.embrapa.br/alice/handle/doc/1099967

Gabarty, A., Salem, H. M., Fouda, M. A., Abas, A. A., \& Ibrahim, A. A. (2014). Pathogencity induced by the entomopathogenic fungi Beauveria bassiana and Metarhizium anisopliae in Agrotis ipsilon (Hufn.). Journal of Radiation Research and Applied Sciences, 7(1), 95-100. https://doi.org/10.1016/j.jrras.2013. 12.004

Galzer, E. C. W., \& Azevedo Filho, W. S. (2016). Utilização do Bacillus thuringiensis no controle biológico de pragas. Revista Interdisciplinar de Ciência Aplicada, 1(1), 13-16. Retrieved from http://www.ucs.br/etc/ revistas/index.php/ricaucs/article/view/4304/2469

Holzhausen, H. G. (2017). Movimentação larval de lepidópteros-praga em soja e milho (56f., Dissertação (Programa de Pós-graduação em Agronomia), Faculdade de Ciências Agrárias e Veterinárias, Jaboticabal).

Ivan, I. A. F., Silva, K. R., Loboschi, D. L., Araujo Jr., L. P., Santos, A. J. P. S., \& Pinto, A. S. (2016). Número de liberações de Telemonus remus no controle de ovos de Spodoptera frugiperda em milho de segunda safra (pp. 284-288). XXXI Congresso Nacional de Milho e Sorgo.

Kaiser, I. S. (2016). Manejo de Agrotis ipsilon (Hufnagel) (Lepidoptera: Noctuidae) com entomopatógenos (58f., Dissertação (Programa de Pós-graduação em Produção Vegetal), Universidade Federal do Espírito Santo, Alegre).

Kuss, C. C., Roggia, R. C. R. K., Basso, C. J., Oliveira, M. C. N., Pias, O. H. C., \& Roggia, S. (2016). Controle de Helicoverpa armigera (Lepidoptera: Noctuidae) em soja com inseticidas químicos e biológicos. Pesquisa Agropecuária Brasileira, 51(5). https://doi.org/10.1590/S0100-204X2016000500013

Machado, D. H. B., Martins, J. L. A., Garcia, L. S., Barbosa, C. H. V., \& Valicente, F. H. (2018). Detecção dos genes inseticidas cryld e crylac em cepas de Bacillus thuringiensis. Revista Brasileira de Ciências da Vida, 6. Retrieved from http://jornal.faculdadecienciasdavida.com.br/index.php/RBCV/article/view/754/361

Madaloz, J. C., \& Policena, E. A. (2018). Estratégia de manejo para o controle de percevejos nas culturas de milho e soja. Agronegócio em Foco. Retrieved from http://www.pioneersementes.com.br/blog/176/ 3-estrategias-de-manejo-para-o-controle-de-percevejos-nas-culturas-do-milho-e-da-soja

Magnabosco, M. E. B. (2018). Nematoides entomopatogênicos visando o controle de Elasmopalpus lignosellus na cultura do milho (89f., Dissertação (Programa de Pós-graduação em Qualidade Ambiental), Universidade Federal de Uberlândia, Uberlândia). 
MAPA (Ministério da Agricultura, Pecuária e Abastecimento), ANVISA (Agência Nacional de Vigilância Sanitária), \& IBAMA (Instituto Brasileiro do Meio Ambiente e dos Recursos Naturais Renováveis). (2006b). Instrução Normativa Conjunta $n^{o}$ 2, de 23 de janeiro de 2006. Brasília: Imprensa Nacional.

MAPA (Ministério da Agricultura, Pecuária e Abastecimento), ANVISA (Agência Nacional de Vigilância Sanitária), \& IBAMA (Instituto Brasileiro do Meio Ambiente e dos Recursos Naturais Renováveis). (2006c). Instrução Normativa Conjunta $n^{\circ} 3$, de 10 de março de 2006. Brasília: Imprensa Nacional.

MAPA (Ministério da Agricultura, Pecuária e Abastecimento), ANVISA (Agência Nacional de Vigilância Sanitária), \& IBAMA (Instituto Brasileiro do Meio Ambiente e dos Recursos Naturais Renováveis). (2006a). Instrução Normativa Conjunta no 1, de 23 de janeiro de 2006. Brasília: Imprensa Nacional.

MAPA (Ministério da Agricultura, Pecuária e Abastecimento). (2010). Ato $n^{\circ} 7$, de 12 de Março de 2010. Brasília: Imprensa Nacional.

MAPA (Ministério da Agricultura, Pecuária e Abastecimento). (2011). Ato $n^{o}$ 29, de 7 de Julho de 2011. Brasília: Imprensa Nacional.

MAPA (Ministério da Agricultura, Pecuária e Abastecimento). (2014). Ato $n^{o}$ 6, de 23 de Janeiro de 2014. Brasília: Imprensa Nacional.

Mattei, D., Henkemeier, N. P., Heling, A. L., Lorenzetti, E., Kuhn, O. J., \& Stangarlin, J. R. (2017). Produtos fitossanitários biológicos disponíveis para agricultura e perspectivas de novos produtos. Ciências agrárias: ética do cuidado, legislação e tecnologia na agropecuária. Marechal Cândido Rondon.

Menezes, R. S., Dumas, V. F., Martins, É. S., Praça, L. B., \& Monnerat, R. G. (2011). Seleção e caracterização de estirpes de Bacillus thuringiensis tóxicas a Agrotis ipsilon. Universitas: Ciências da Saúde, 8(2), 1-13. https://doi.org/10.5102/ucs.v8i2.1142

Oliveira, A. B., Prando, A. M., Conte, O., Lima, D., Teixeira, F. T., Harger, N., ... Tavares, L. C. V. (2018). Rede de manejo integrado de pragas (MIP) em soja no Paraná-Safras 2012/13 a 2016/17. Congresso Brasileiro de Soja, Goiânia. Retrieved from https://ainfo.cnptia.embrapa.br/digital/bitstream/item/178953/1/Rede-demanejo-integrado-p.83-85.pdf

Oliveira, H. N., \& Ávila, C. J. (2010). Controle biológico de pragas no Centro-Oeste brasileiro. Revista de Controle Biológico (pp. 11-13).

Oliveira, R. P., Pessoa, L. G. A., Loureiro, E. S., \& Oliveira, M. P. (2018). Compatibilidade de inseticidas utilizados no controle da mosca branca em soja com Beauveria bassiana. Revista de Agricultura Neotropical, 5(4), 88-93. https://doi.org/10.32404/rean.v5i4.2416

Parra, J. R. P. (2019). Tecnologia consolidada: Trichogramma no manejo de lepidópteros. Revista Cultivar. ESALQ/USP.

Pasini, R. A., Grützmacher, A. D., Spagnol, D., Armas, F. S., Normberg, A. V., \& Carvalho, H. J. S. (2017). Ação residual de agrotóxicos pulverizados em plantas de milho sobre Trichogramma pretiosum. Revista Ceres, 64(3), 242-249. https://doi.org/10.1590/0034-737x201764030004

Picanço, M. C. (2010). Manejo integrado de pragas. Universidade Federal de Viçosa, Viçosa, Brazil.

Pinto, O. D. B. B., Taguti, E. A., Bueno, A. F., \& Favetti, B. M. (2017). Biologia de Telenomus podisi Ashmead (Hymenoptera: Scelionidae) em ovos de Dichelops melacanthus (Dallas) (Hemiptera: Pentatomidae) submetidos a diferentes temperaturas. XII Jornada Acadêmica da Embrapa Soja.

Ribeiro, C. I., Coelho, C. C. S., Rocha, M. R., Martins, L. O., Damasceno, N. C., Souza, C. F. S., \& Mendes, S. M. (2017). Capacidade predatória de Doru luteipes e Euborellia annulipes sobre Helicoverpa armigera. Embrapa Milho e Sorgo, Brazil.

Rocha, A. C. P. (2016). Dinâmica de interações tróficas de Euschistus heros (Hemiptera: Pentatomidae) com Telenomus podisi e Trissolcus basalis (Hyminoptera: Platygastridae) (p. 106, Tese (Doutorado em Entomologia), Universidade de São Paulo, Piracicaba).

Rodrigues, I. M. W., Forim, M. R., Silva, M. F. G. F., Fernandes, J. B., \& Filho, A. B. (2016). Effect of ultraviolet radiation on fungi Beauveria bassiana and Metarhizium anisopliae, pure and encapsulated, and bio-insecticide action on Diatraea saccharalis. Advances in Entomology, 4, 151-162. https://doi.org/ 10.4236/ae.2016.43016 
Santos, A. E. S., \& Cruz, I. (2017). Metodologia de criação da Diatraea saccharalis. Embrapa Milho e Sorgo, Brazil.

Santos, C. A., Marucci, R. C., Barbosa, T. A. N., Araujo, O. G., Waquil, J. M., Dias, A. S., ... Mendes, S. M. (2016). Desenvolvimento de Helicoverpa spp. em milho Bt com expressão de diferentes proteínas. Pesquisa Agropecuária Brasileira, 51(5), 537-544. https://doi.org/10.1590/S0100-204X2016000500014

Santos, J. R., Maia, A. G. F., Costa, A. F., Godoy, M. S., \& Silva, R. I. R. (2018). Eficiência de métodos de controle na supressão da Spodoptera frugiperda (Smith) na cultura do milho. Revista Inova Ciência \& Tecnologia, 4(1), 7-13. Retrieved from http://periodicos.iftm.edu.br/index.php/inova/article/view/360/263

Secchi, V. A. (2002). Baculovírus, mais do que uma grande descoberta: Uma revolucionária alternativa aos agrotóxicos. Agroecologia e Desenvolvimento Rurural Sustentável, 3(3). Retrieved from http://docplayer. com.br/51125185-Baculovirus-mais-do-que-uma-grande-descoberta-uma-revolucionaria-alternativa-aos-agr otoxicos.html

Silva, G. M. (2018). Uso de Cotesia flavipes (cam.) no controle de Diatraea saccharalis,(fabr.) em cana-de-açúcar na zona da mata norte de Pernambuco. Universidade Federal da Paraíba, Areia, Brazil. Retrieved from https://repositorio.ufpb.br/jspui/handle/123456789/3546

Siminato, J., Grigolli, J. F. J., \& Oliveira, H. N. (2014). Controle Biológico de Insetos-Praga na Soja. Embrapa Agropecuária Oeste, Capítulo em Livro Técnico Científico.

Simonato, J. (2018). Avaliação do potencial de inimigos naturais no controle Biológico de helicoverpa armigera (Hübner, 1805) (lepidoptera: Noctuidae) (Tese, 96f., (Programa de Pós-Graduação em Entomologia e Conservação da Biodiversidade), Universidade Federal da Grande Dourados, Dourados).

Sousa, G. L. A. (2016). Lagarta-elasmo na cultura do milho. Universidade Federal de Lavras-3rlab. Retrieved from https://3rlab.wordpress.com/2016/06/22/lagarta-elasmo-na-cultura-do-milho

Valicente, F. H. (2015). Manejo Integrado de Pragas na Cultura do Milho. EMBRAPA Milho e Sorgo, Circular Técnica, Sete Lagoas, MG. Retrieved from https://ainfo.cnptia.embrapa.br/digital/bitstream/item/125260/1/ circ-208.pdf

Xavier, L. M. S., Laumann, R. A., Borges, M., Magalhães, D. M., Vilela, E. F., \& Moraes, M. C. B. (2011). Trichogramma pretiosum attraction due to the Elasmopalpus lignosellus damage in maize. Pesquisa Agropecuária Brasileira, 46(6), 578-585. https://doi.org/10.1590/S0100-204X2011000600002

Zambiazzi, E. V., Corassa, J. de N., Guilherme, S. R. E., \& Bonaldo, S. M. (2012). Controle biológico in-vitro do percevejo-marrom (Euschistus heros) com Beauveria bassiana. Revista Trópica-Ciências Agrárias e Biológicas, 6(2), 43-48. https://doi.org/10.0000/rtcab.v6i2.534

Zambiazzi, E. V., Guilherme, S. R., Corassa, J. N., Bonaldo, S. M., Zuffo, A. M., Soares, I. O., \& Oliveira, E. D. C. S. (2016). Patogenicidade de Beauveria bassiana no controle in vitro da lagarta-da-espiga do milho (Helicoverpa zea). Revista de Ciências Agrárias, 39(1). https://doi.org/10.19084/RCA15002

Zorzetti, J., Ricietto, A. P. S., Fazion, F. A. P., Meneguim, A. M., Neves, P. M. O. J., \& Bôas, G. T. V. (2017). Isolation and characterization of Bacillus thuringiensis strains active against Elasmopalpus lignosellus (Zeller, 1848) (Lepidoptera, Pyralidae). Acta Scientiarum Agronomy, 39(4), 417-425. https://doi.org/ 10.4025/actasciagron.v39i4.32707

\section{Copyrights}

Copyright for this article is retained by the author(s), with first publication rights granted to the journal.

This is an open-access article distributed under the terms and conditions of the Creative Commons Attribution license (http://creativecommons.org/licenses/by/4.0/). 